\title{
Paideusis
}

\section{Education, Values and Mind: Essays for R.S. Peters (David E. Cooper (Ed.))}

William Hare

Volume 2, Number 1, 1988

URI: https://id.erudit.org/iderudit/1073420ar

DOI: https://doi.org/10.7202/1073420ar

See table of contents

Publisher(s)

Canadian Philosophy of Education Society

ISSN

0838-4517 (print)

1916-0348 (digital)

Explore this journal

Cite this review

Hare, W. (1988). Review of [Education, Values and Mind: Essays for R.S. Peters (David E. Cooper (Ed.))]. Paideusis, 2(1), 29-31.

https://doi.org/10.7202/1073420ar

This document is protected by copyright law. Use of the services of Erudit (including reproduction) is subject to its terms and conditions, which can be viewed online.

https://apropos.erudit.org/en/users/policy-on-use/
This article is disseminated and preserved by Érudit.

Érudit is a non-profit inter-university consortium of the Université de Montréal, Université Laval, and the Université du Québec à Montréal. Its mission is to promote and disseminate research.

https://www.erudit.org/en/ 


\section{Book Reviews}

David E. Cooper (ed.), Education, Values and Mind: Essays for R.S. Peters (London: Routledge and Kegan Paul, 1986).

This collection of essays, all previously unpublished with the exception of the contribution from Scheffler, is essentially a festschrift to mark the recent departure of R.S. Peters from centre stage in philosophy of education, a position he occupied for some twenty years. The first essay, suitably enough, is by Paul Hirst, Peters' long-time collaborator, who characterizes Peters' overall contribution as an attempt to articulate and defend an approach to education committed to liberal values. The account is succinct, accurate, and sympathetic, with some suggestions as to where the defence falters and where further work is needed.

To my mind, the essay is marred by an opening historical sketch which is basically an old-fashioned "great man" interpretation, and extremely simplistic. Twenty-five years on, it is surely possible to see links with earlier work, including that of Russell and Whitehead, which were no doubt blurred at the time. Hirst's remarks, however, perpetuate the view that there was darkness and suddenly light. A similar exaggeration enters in when, towards the end of Hirst's contribution, we are told that Peters' study of moral education "stands alone as a coherent and comprehensive statement of what the enterprise involves." Predictable in a festschrift perhaps, but preposterous all the same. There is not a word, here or elsewhere, concerning the charge that Peters' account presents a masculine ideal, a criticism which raises a serious doubt about how comprehensive the account actually is.

Fortunately, the historical distortion is rectified in the very next chapter by R.K. Elliott who develops the thesis that Peters is to be seen as a philosopher "in the older style," one who sets out a general philosophy of life. By means of an extended and unexpected comparison with Heraclitus, Elliott shows how a certain world view permeates Peters' writings. In various articles which have received limited attention, perhaps because they were delivered to a general audience, Elliott finds a general framework of beliefs, including passionate concern for truth, the value of discussion, and the need to discover significance within life, which provide a coherent setting for the more specific positions defended in what is regarded as Peters' more analytical and definitive work.

Robert Dearden returns to, and develops, a theme which he has recently explored elsewhere as he takes up the question of Peters' analysis of the distinction between education and training, especially 
as that distinction applies to the preparation of teachers. Once again, we find that clarity and conciseness for which Dearden's work is renowned. He argues that Peters defends a conception of liberal education which infiltrates his approach to teacher preparation, an approach which Dearden sees as especially relevant in the present climate where the "illusion of uncontroversiality" has taken hold. In connection, however, with Dearden's minimalist analysis of education as learning which enhances understanding, it might be suggested that this alone is sufficient to rule out indoctrination if the latier is such that it seeks to curb understanding in arbitrary ways. An implicit. appeal to a more particular liberal conception may not be involved.

Readers familiar with Anthony O'Hear's Education, Society and Human Nature will welcome his latest contribution to the defence of those rational values which were central to Peters' vision of education. O'Hear is absolutely right that these are under attack and that it is a fundamental task of philosophy of education to explain their meaning and significance. He illustrates this conviction in a detailed critique of the conservative views of F.A. von Hayek. In a move reminiscent of Stephen Stich on the doomsday scenario argument in science, O'Hear pointedly asks how we can be sure that noninterference in social and economic processes is more rational than interference.

John and Patricia White examine the merits of liberalism in education - equipping children to form a life-plan, and providing basic moral education - against the rival claims of a Macintyreinspired virtues conception. They conclude with a preference for the latter, but the whole discussion has the air of an artificial either-or problem. Liberalism slides from requiring all that is necessary to form a life-plan to requiring an acquaintance with as many options as possible. Such ambiguities breed caricature.

Mary Warnock writes in characteristically incisive manner on the education of the emotions. While agreeing that this will include ensuring that the beliefs which prompt emotions are true, and learning to control one's emotions, she also recognizes an habituation process (where a genuine emotion emerges from an earlier pretence), and teaching one's subject in such a way that certain emotions, especially hope, are fostered. Not a special lesson, we might say, but a special responsibility in any teaching reflecting the centrality of feeling in moral education.

Alan Montefiore takes up the problem of justifying respect for persons, which Peters had addressed in Ethics and Education, and he examines the adequacy of the well-known transcendental argument. It is not clear, however, that Montefiore's counter-arguments take account of leters' qualification that the argument "relates to prima facie principles which a man must in general accept."

Michacl Bonnett writes on "Personal authenticity and public 
standards" and argues that Peters to his credit has successfully challenged a number of fashionable dichotomies with respect to the development of mind. Bonnett believes, however, that the importance of the authentic response which seeks to transcend existing public standards has been neglected. The puzzle is to see how this complaint can with justice be directed against Peters who, after all, stresses the importance of revising the traditions into which we have been initiated and who denies that philosophers are merely the prisoners of the presuppositions of their age.

Two papers in the collection seem to me misfits. Hamlyn's chapter on motivation certainly deals with a topic which attracted Peters' attention, but there is no attempt to relate the discussion to any educational issue and, despite the editor's protestations, I cannot see that it merits a place in a volume in the International Library of Philosophy of Education. Scheffler's discussion of "Human nature and potential", fine as it is, was writlen quite independently and does not develop or examine any aspect of Peters' thought. One can only regret that we do not find Scheffler on Peters and hope that it may yet appear.

This collection will be of most value to graduate students and scholars who wish to explore the character and direction of Peters' thought. It is a great pity, therefore, that more care was not taken with the bibliography of Peters' publications. It really is shoddy. First, it is not complete, yet certain contributors claim that important ideas are tucked away in lesser known works. Second, there are numerous errors and other shortcomings. Peters did not write on "Emotions and the category of possibility". The book edited by B.P. Komisar and C.J.B. MacMillan is actually entitled Psychological Concepts in Education. The reference to The Discipline of Education by John Walton and James Kuethe omits the editors' initials and misspells Kuethe's name. The original date of publication is not always given, as with the article co-authored with John White which originally appeared in 1969. Page numbers are not cited for articles. An opportunity has been lost to have a definitive bibliography in a convenient place.

William Hare

Dalhousie University 